\title{
The Application of British Parliamentary Debate in College English Classroom from Multimodal Perspective
}

\author{
Lu Lu \\ School of English for International Business, Guangdong University of Foreign Studies, \\ Guangzhou, China
}

\begin{abstract}
The application of British Parliamentary debate in Chinese college English classroom is an effective way to create multimodal communication environment, so as to trigger students' interest in learning as well as to improve their communicative skills and critical thinking. This paper provides a theoretical analysis of the effectiveness of BP from multimodality perspective. A detailed instruction of how to conduct a BP in the classroom is also provided.
\end{abstract}

Keywords: Multimodal, BP, debate, English teaching

\section{Introduction}

By definition, multimodality means information passed by three or more than three sensing channels ${ }^{[1]}$. Halliday considers that language is only one of the many ways that people communicate and exchange information with each other. To be specific, in oral communication, information is also passed via intonation, speed, and body language. In written texts, apart from words, there are charts and pictures to facilitate the expression of ideas. With the development of modern technology, especially the development of multimedia, other means of communication have become as important as langue. People read newspapers and magazines, watch TV and advertisements, use computers to get in touch with the world.
Therefore, the communication among people nowadays is more "multimodal" then ever before.

College English teaching in China has undergone dramatic changes in recent years. The application of multimedia and computer assisted teaching methods have become prevalent. Not only have the teaching materials-PPT, Video, and ect.- been widely used in classrooms, but also the teaching methods are more flexible: from teacher-centered to student-centered by adapting various in-class activities which involve students' participation, such as role-play and presentation. It is in this social and educational context in China that the multimodal teaching mode emerges and develops. The realization of multimodality in teaching is an irresistible trend, but at the same time it requires educators and teachers to explore new ways constantly, rather than stick to the traditional and existing ones, to teach their students.

How to make full use of the new media and technology when a debate is conducted always deserves our attention, because new technologies advance at such a speed as there are always better ways for students to learn. This paper will provide a theoretical analysis of the application of British Parliamentary Debate (BP) from the multimodal perspective. Then a detailed instruction about how to carry out a BP debate in an English classroom will be given. 


\section{Theoretical basis of multimodality}

The theoretical basis of multimodal pedagogy is a multimodal discourse analysis theory emerged in the 1990s. It suggests that images, sounds and movements are all social symbols. Multimodal pedagogy is based on Halliday's systematic functional linguistics ${ }^{[2]}$. In the early 21 st century, the study of multimodality in educational field triggered great interest among researchers. Stein ${ }^{[3]}$ holds that the communication in the classroom is multimodal, therefore the design of curriculum, the teaching-learning process, and the assessment should all be multimode. He points out that students read a drama along and act it out may result in totally different learning effects. In addition, Kress' research on children's literacies and meaning construction, van Leeuwen's research on the materiality of the resources of sound, and Royce's proposition of multimodal teaching methodology have all contributed to the recent and future research on multimodal pedagogy.

Multimodal pedagogy is a term first put forward by New London Group in 1996. It is a theory which advocates the use of different teaching methods and materials to trigger students' interest in learning. The traditional foreign language teaching mainly focuses on language, but didn't pay adequate attention to other communication channels. With the development of modern technology and multimedia, the communication between teachers and students becomes multimodal. Language is no longer the carrier of all meaning. Therefore, it is important to make full use of images, sounds, facial expressions, movements and ect. in an English classroom.

\section{Multimodality and debate}

Multimodal discourse analysis breaks the confines of monolingual communication mode, and instead focuses on both verbal and nonverbal information. It also focuses on how different modes of communication interact with each other and collaboratively convey the idea of the speaker. The research findings have been applied to teaching practices in China and many countries in the world, and provide theoretical guidance for the teaching of listening, reading, speaking and writing.

Debate is an ancient science and art. At the same time it is a very popular teaching practice in the west. The efficacy of debate in language classroom has long been studied and proofed ${ }^{[4-6]}$. Debate can help students in mainly four aspects: 1) improve their critical thinking ${ }^{[4]}$; 2) improve their language $\mathrm{s}$ kills ${ }^{[4-6]}$; 3) help build students' knowledge base ${ }^{[5-6]}$; 4) help build up students' self confidence and teamwork spirit. As a result, it is both feasible and helpful to bring debate into the language classroom.

Debate can be seen as the exchange of information in a specific occasion, where speakers need to use verbal and nonverbal communication skills to realize the transmission of ideas. In a debate, speakers need to use gestures, eye contact, paralanguage and ect. to help their expression of ideas and feelings. Hence, debate can be regarded as a multimodal discourse. In addition, in order to prepare for the debate, students have to read books and surf the internet to get enough information. During the debate, teachers can resort to multimedia, such as videotaping students' performance, to facilitate their teaching. After the debate, students can get feedback from the teachers from different channels-for example, 
Blackboard, software which creates online virtual learning environment. Compared to face-to-face interaction, these new teaching means are more interesting and more flexible, because they may improve students' enthusiasm in learning by providing more chances for students to get involved in the class.

As a result, both debate itself and the way to conduct a debate are closely related to multimodality. To look at debate under the context of multimodality is to find better ways to help students in their learning of language, and make the most of the new media and technology.

\section{The application of $B P$ in the language classroom}

The British Parliamentary debate is a highly subtle art, featuring four teams, of two members each. The teams are classified as the 'Proposition' and the 'Opposition', based on whether they are supporting or speaking against the motion, respectively. Every debate has a motion, which is the issue of discussion. During the debate, each side should take at least two POI(Point of information), which aims to question or counter-argue the points raised by the opposite side.

In China, BP becomes known by teachers and students since 1990s. Thanks to the prevalence of national debate contests, for example, the debate tournament held by Foreign Language Teaching and Research Publication, more and more people are interested in the BP. Educators start to study on the benefits BP has on English learners. Compared to other forms of debate, BP has the advantage in two main aspects: 1) Practices multimodal literacies. In order to conduct a debate, students have to use various means to collect information, as BP is nothing the same as other forms of debate, where debaters can resort to their common sense to argue for themselves. In the BP, one cannot debate well without a large amount of background information, because s/he needs to argue for or against a motion. Whether to pass a motion depends on the real conditions of a country or the status quo. Students usually are highly motivated to collect information and data via different channels. 2) Broadens students' horizons. Motions are usually related to the hottest issues in the society and the world. Students may need to step out of the confines of textbooks to find evidences to support themselves in the debate.

BP can be carried out under the multimodal mode in the following three steps:

Step 1: Preparation before the debate

Give a motion to the students before the debate. Assign roles to each student (Prime Minister and Deputy Prime minister as the opening Government, Leader of the Opposition and Deputy Leader of the Opposition as the opening opposition, Member of the Government and Government Whip as the Closing Government, and Member of the Opposition and Opposition Whip as the Closing Opposition). Make sure every team as the above roles. Students are required to know the rules of the debate (including the sequence of speech, how and when to take POI, ect.). Students of the same role are encouraged to prepare together and share information. Teachers may provide guidance to the students as how to use multimedia to find information. The purpose of this step is to train students' research skills, reading skills, and teamwork spirit.

Step 2: In-class debate

First, conduct the debate within small groups. The teacher can be the timer. This is to make sure every student has the opportunity to speak out. Then the teacher 
invites eight students, each playing his/her original role in the small group, to perform in front of the whole class. This is to provide a discourse for every student in the class to evaluate. After that, the teacher may ask the students for their comments on debaters' ideas-rather than language onlydelivery, organization, logic, and ect.. Teachers need to provide detailed comments after this. Also, teachers can show relevant audio and visual materials, such as debate videos, to reinforce students' understanding of the motion. In this stage, students are supposed to practice their listening and speaking skills, and at the same time develop their critical thinking.

Step 3: After the debate

The debate doesn't end here. On one hand, students may need time to reflect upon their own performances in the class. On the other hand, after the debate students might be inspired and have new thoughts on the motion. It is a good idea to ask the students to take side on the motion and write an argumentation to illustrate their viewpoints. Also, the teachers can use Blackboard to ask students for their feedbacks of the debate. Students are free to express their opinions on the motion (whether to pass it or not and why). They can also discuss social issues related to the motion. It's a good way for teachers to know their students better, and lead them to think deeper about the motion.

In short, the application of BP debates provides students with multimodal learning environment, strengthens and realizes language input and output by visual and sound resources, and ultimately improves students' communicative skills and critical thinking.

\section{Conclusion}

Under the trend of multimodality, the application of multimedia and new technology is irresistible. To look at BP from multimodality perspective is an attempt to explore new ways to teach English. Its purpose is to create multimodal learning environment by using various communication channels. A well designed BP debate can provide students with opportunities to practice their communication skills and improve their critical thinking. However, this practice requires teachers to design activities carefully. Also, teachers need to have good command of knowledge to guide the debate and give feedback to the students. These are challenges to teachers in China.

This paper is supported by the 2012 Guangdong province education and research "the firth twelve" project(2012JK128) and the 2011 Youth Project of Guangdong University of Foreign Studies (11Q17, GWJYQN1005)

\section{References}

[1] Y. Gu, "Study on multimedia, multimodal learning," ComputerAssisted Foreign Language Education, Vol. 4 pp 11-12, 2007.

[2] O'Toole $\mathrm{M}$, The Language of Displayed Art [M], London: Leicester University Press, 1994.

[3] Stein, P. Rethinking Resources: Multimodal Pedagogies in the ESL Classroom [J], TESOL QUARTERLY, (34) pp. 333-336, 2000.

[4] Yin. Songtao, Study on the realation between English debate and college English reform [J], Higher Education Research,(3) pp. 33-35, 2006.

[5] Lin, Yan. Oral education and the development of critical thinking, For-eign Languages and Their Teaching, (5) pp. 29-33, 2012. 
[6] Alfaro-Lefevre, R. Critical Think-ing in Nursing: A Practical Approach

[M] , Philadelphia: Saunders, 1995. 